\title{
New Silicotitanate Waste Forms: Development and Characterization
}

(Project Number: 60345)

\section{Principal Investigator}

Mari Lou Balmer

Pacific Northwest National Laboratory

P.O. Box 999, MSIN K8-93

Richland, WA 99352

(509) 376-2006 (phone)

lou.balmer@pnl.gov

\section{Co-Investigators}

Tina Nenoff

Sandia National Laboratories

P.O. Box 5800

Albuquerque, NM 87185-0709

(505) 844-0340 (phone)

tmnenof@sandia.gov

\author{
Alexandra Navrotsky \\ Department of Chemical Engineering and Material Science \\ University of California-Davis \\ Davis, CA 95616 \\ (916) 752-3292 (phone) \\ anavrotsky@ucdavis.edu \\ Yali Su \\ Pacific Northwest National Laboratory \\ P.O. Box 999, MSIN K8-93 \\ Richland, WA 99352 \\ (509) 376-5290 (phone) \\ ya.su@pnl.gov
}

\section{Contributors and Collaborators}

Bob Roth (NIST)

Hongwu Xu (UC Davis)

May Nyman (SNL)
Eric Bitten (PNNL)

Dave McCready (PNNL)

Rod Ewing (U Mich) 


\section{Research Objective}

The objective of this program is to identify new waste forms and disposal strategies specific to crystalline silicotitanate (CST) secondary waste that is generated from cesium and strontium ion exchange processes. Waste forms that are developed in this work will offer an alternative to current disposal plans. The goals of the program are to reduce the costs associated with CST waste disposal, minimize the risk of contamination to the environment during CST processing, and provide DOE with technical alternatives for CST disposal. The technical objectives of the proposed work are to 1) fully characterize the phase relationships, structures, and thermodynamic and kinetic stabilities of crystalline silicotitanate waste forms and 2) establish a sound technical basis for understanding key waste form properties, such as melting temperatures and aqueous durability, based on an in-depth understanding of waste form structures and thermochemistry.

\section{Research Progress and Implications}

This report summarizes work after two years and three months of a three-year project. To date, studies have been performed to 1) determine the durability of waste forms synthesized by heat-treating the UOP CST IE-911, 2) investigate the stable and metastable phase formation, especially the cesium-containing phases from heat-treated CST and from model three-component systems, and 3) investigate thermodynamic stabilities of compounds related to the ion-exchanged CST and the thermally converted oxides.

\section{Durability of Thermally Converted CST}

The durabilities of several Cs-loaded, thermally converted CST waste forms have been measured. The Cs-exchanged materials were heat-treated to temperatures ranging from $500^{\circ}$ to $1000^{\circ} \mathrm{C}$, analyzed by $\mathrm{x}$-ray diffraction (XRD) for phase selection, then characterized for chemical durability. Chemical durability was measured using the standard product consistency test (PCT) and the MCC-1 leach test. The leach rates were extremely low, ranging from $10^{-8}$ to $0.002 \mathrm{~g} / \mathrm{m}^{2} \bullet$ day. The untreated $500^{\circ}$ and $900^{\circ} \mathrm{C}$ materials exhibited the lowest Cs leach rates, and the total fraction of Cs released for these samples was less than $1 \mathrm{wt} \%$ after seven days. These thermally converted waste forms are several orders of magnitude more durable than borosilicate glass. The aqueous durability behavior, as measured by the PCT test, for both asreceived and Na-exchanged IE-911 loaded to $5 \mathrm{wt} \%$ and $12-\mathrm{wt} \% \mathrm{Cs}$ did not show any significant differences. Leach rates measured using the MCC-1 test were even lower than those measured by the PCT test, as expected.

The durability tests show that heat-treated IE-911 with no additives can result in a chemically durable waste form. Thermogravimetric and differential thermal analysis of Cs-exchanged and $\mathrm{Na}$, Cs-exchanged IE-911 was performed to determine decomposition and crystallization temperatures. This analysis revealed that all molecular water is desorbed by $400^{\circ} \mathrm{C}$, and hydroxyl groups are removed near $800^{\circ} \mathrm{C}$. Therefore, the risk of radiolytic hydrogen production during short- or long-term storage is eliminated by heat-treating the ion exchanger to temperatures above $800^{\circ} \mathrm{C}$. The volume reduction of a pellet heat-treated to $900^{\circ} \mathrm{C}$ is $40 \%$. 


\section{Structure/Property Relationship Studies}

\section{Phase Selection of Thermally Converted CST}

Phase stability and crystal chemistry studies for compositions related to the exchanger are vital to predicting long- and short-term performance of waste forms. Cs-loaded IE-911 contains six or more constituents, including $\mathrm{Cs}_{2} \mathrm{O}, \mathrm{Na}_{2} \mathrm{O}, \mathrm{SiO}_{2}, \mathrm{TiO}_{2}$, binder, and proprietary components. While the phase relationships between some of the binary and ternary components of the CST are available in the literature, the phase selection and durabilities of more complex compositions that represent the loaded exchanger are unknown.

X-ray diffraction of heat-treated IE-911 powders shows that the single-phase metastable ion exchanger structure is destroyed above $500^{\circ} \mathrm{C}$, and then at higher temperatures stable multiphase crystalline mixtures precipitate. Positive identification by XRD had already been achieved for the sodium titanate phase, $\mathrm{Na}_{2} \mathrm{Ti}_{6} \mathrm{O}_{13}$. To determine whether small amounts of cesium could reside in the $\mathrm{Na}_{2} \mathrm{Ti}_{6} \mathrm{O}_{13}$ structure, a solid substitution series of $(\mathrm{Na}, \mathrm{Cs})_{2} \mathrm{Ti}_{6} \mathrm{O}_{13}$ was synthesized, and the lattice parameters were measured by XRD. This study surprisingly revealed that there is no measurable substitution of cesium for sodium on the $\mathrm{Na}_{2} \mathrm{Ti}_{6} \mathrm{O}_{13}$ lattice, eliminating the possibility that small amounts of cesium could reside in this phase in heat-treated IE-911.

${ }^{133} \mathrm{Cs}$ magic angle spinning (MAS) nuclear magnetic resonance (NMR) measurements were performed to reveal the local environment around the Cs atom. The NMR spectra for $\mathrm{NaOH}-$ treated, Cs-exchanged IE-911 heat-treated over a range of temperatures indicate that the Cs environment in the as-received exchanger is destroyed above $500^{\circ} \mathrm{C}$. Broadening in the NMR spectrum at $500^{\circ} \mathrm{C}$ indicates that the material is becoming amorphous. At $700^{\circ} \mathrm{C}$ a new Cscontaining phase forms, and by $800^{\circ} \mathrm{C}$ the original Cs environment is completely gone and the Cs is in only one crystalline environment.

A transmission electron microscopy (TEM) study was performed to evaluate the phase selection of thermally converted CST. Among these were Cs, X1, Si oxide, Na, Ti oxide, Na, Ti, $\mathrm{X} 2$ oxide, and very minor $\mathrm{Na}, \mathrm{Cs}, \mathrm{Ti}, \mathrm{Si}, \mathrm{X} 1$ oxide, where $\mathrm{X} 1$ and $\mathrm{X} 2$ are proprietary components of the ion exchanger. TEM revealed that the majority of the cesium is contained in a Cs, $\mathrm{X} 1$, Si oxide. This phase was successfully synthesized using solid-state reaction, sol gel, and hydrothermal reactions. The stoichiometry of the phase is $\mathrm{Cs}_{2} \mathrm{X}_{1} \mathrm{Si}_{3} \mathrm{O}_{9}$. Rietveld refinement of $\mathrm{x}$-ray powder diffraction data showed that $\mathrm{Cs}_{2} \mathrm{X}_{1} \mathrm{Si}_{3} \mathrm{O}_{9}$ has a hexagonal structure (space group $\mathrm{P} 63 / \mathrm{m}$ ) with lattice parameters $\mathrm{a}=7.2303(2) \AA, c=10.2682(4) \AA$. The simulated crystal structure based on the atomic positions of the isomorph and the lattice parameters of $\mathrm{Cs}_{2} \mathrm{X}_{1} \mathrm{Si}_{3} \mathrm{O}_{9}$ is shown in Figure 1. It consists of silica tetrahedra and X1 octahedra that form three- and six-membered rings. The largest free aperture of the rings is approximately $2.2 \times 2.6 \AA$, which is smaller than a cesium atom $(\sim 3.5 \AA)$. Therefore, the cesium in this phase will be immobile. Removal of cesium from the structure will require the cleavage of the strong, covalent Si-O and X1-O bonds. This structural feature in part explains the high resistance to leaching of cesium in thermally converted IE-911 that is exposed to aqueous solutions. 


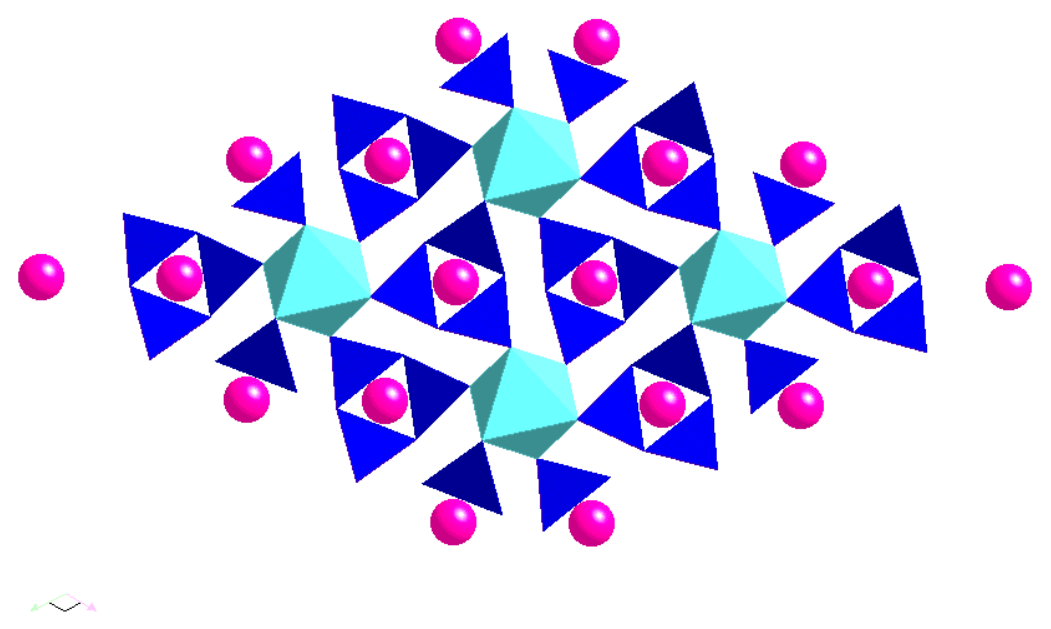

Figure 1. View of $\mathrm{Cs}_{2} \mathrm{X} 1 \mathrm{Si}_{3} \mathrm{O}_{9}$ Structure Down the [001] Directions. This is the major cesium-containing phase in thermally converted $\left(900^{\circ} \mathrm{C}\right) \mathrm{IE}-911$.

Radiation stability studies (by gamma irradiation in the PNNL ${ }^{60} \mathrm{Co}$ source as well as by in situ TEM electron beam with the collaboration of Prof. Rod Ewing in University of Michigan) are in progress. Preliminary results from in-situ TEM electron irradiation show amorphization after an electron fluence of $1.1 \times 10^{22} \mathrm{e} / \mathrm{cm}^{2}$.

A second new phase discovered in TEM ( $\mathrm{Na}, \mathrm{Ti}, \mathrm{X} 2$, oxide) has a structure similar to $\mathrm{NaX} 2 \mathrm{O}_{3}$. To determine the extent of titanium substitution in the mixed phase, a series of compounds with up to $20 \%$ titanium substituted for X2 were synthesized using a sol gel technique. A systematic shift of the lattice parameter as a function of titanium substitution could clearly be observed. Comparison of the heat-treated IE-911 with the synthesized compounds revealed that the phase in IE-911 has $15 \%$ titanium substitution on the lattice. The structure of the new compound is related to a perovskite; however, the distribution of the cations in the structure is unknown.

\section{Stable Phases in $\mathrm{Cs}_{2} \mathrm{O}-\mathrm{TiO}_{2}-\mathrm{SiO}_{2}$ System}

Phase equilibria studies in the model system, $\mathrm{Cs}_{2} \mathrm{O}-\mathrm{TiO}_{2}-\mathrm{SiO}_{2}$, are being performed to identify the stable compounds and determine their compositional regions of stability. The phase relationships for compositions related to the ion exchanger will provide information necessary for setting optimal composition and temperature regimes for processing the final waste form and will elucidate the effects of minor compositional variations.

Two new high-temperature, durable, high-Ti crystalline zeolitic phases, $\mathrm{CsTiSi}_{2} \mathrm{O}_{6.5}$ and $\mathrm{Cs}_{2} \mathrm{TiSi}_{6} \mathrm{O}_{15}$, were synthesized and characterized. $\mathrm{CsTiSi}_{2} \mathrm{O}_{6.5}$ has a crystal structure isomorphous to the mineral pollucite, $\mathrm{CsAlSi}_{2} \mathrm{O}_{6}$, with $\mathrm{Ti}^{+}$replacing $\mathrm{Al}^{+}$. The structure of 
$\mathrm{Cs}_{2} \mathrm{TiSi}_{6} \mathrm{O}_{15}$ is unique; titanium octahedra and silicon tetrahedra forming an open framework structure with the $\mathrm{Cs}$ residing in large cavities. The largest covalently bonded ring opening to the Cs cavities in both compounds is smaller than a Cs ion, revealing that Cs ion has minimal mobility in the structure. Therefore, both compounds have exceptional resistance to leaching. Single crystal growth experiments have produced a new tetragonal structure that is similar to cubic pollucite $\left(1: 2: 4 \mathrm{Cs}_{2} \mathrm{O}-\mathrm{TiO}_{2}-\mathrm{SiO}_{2}\right)$ but with extended $\mathrm{TiO}_{2}$ solubility. In addition, a new compound with stoichiometry $1: 1.2: 1.7 \mathrm{Cs}_{2} \mathrm{O}-\mathrm{TiO}_{2}-\mathrm{SiO}_{2}$ has been identified. Crystal structure determination of these new compounds is in progress.

A complete solid solution substitution series of $\mathrm{CsTiSi}_{2} \mathrm{O}_{6.5}$ and $\mathrm{CsAlSi}_{2} \mathrm{O}_{6}$, has been synthesized. These are interesting because the substitution of aluminum by titanium is chargebalanced by the incorporation of additional oxygen ions, converting four-coordinated aluminum to five-coordinated titanium. Thus the rather unusual ionic substitution $\mathrm{Al}^{3+}=\mathrm{Ti}^{4+}+1 / 2 \mathrm{O}^{2-}$ is occurring. Lattice parameters and titanium contents vary in a complex way, especially for Tirich compositions. Subambient cubic-to-tetragonal phase transitions in Ti/Al pollucite were studied by $\mathrm{x}$-ray powder diffraction. Under ambient conditions, $\mathrm{CsAlSi}_{2} \mathrm{O}_{6}$ is cubic (space group Ia3d); at subambient temperatures, the structure is tetragonal (space group I4/acd). Substitution of $\mathrm{Ti}$ for $\mathrm{Al}$ in pollucite $\left(\mathrm{CsAl}_{1-\mathrm{x}} \mathrm{Ti}_{\mathrm{x}} \mathrm{SiO}_{6+\mathrm{y}}\right)$ resulted in stabilization of the cubic structure at low temperature (to $100 \mathrm{~K}$ ).

\section{Metastable Phases in $\mathrm{Cs}_{2} \mathrm{O}-\mathrm{TiO}_{2}-\mathrm{SiO}_{2}$ System}

Researchers at Sandia National Laboratories (SNL) are studying the metastable phase development in the component systems that represent the cesium-loaded ion exchanger. This work complements the stable phase development studies at PNNL and allows for a complete understanding of the phase development from the metastable ion exchanger to the stable ceramic waste form. Hydrothermal $\mathrm{Cs}_{2} \mathrm{O}-\mathrm{TiO}_{2}-\mathrm{SiO}_{2}$ ternary phase searches have produced two novel phases, which we have designated SNL-A and SNL-B. The stability regions of these phases as a function of $\mathrm{Cs}_{2} \mathrm{O}: \mathrm{TiO}_{2}: \mathrm{SiO}_{2}$ precursor ratio $($ and $\mathrm{pH})$ are plotted on the ternary diagram in Figure 2. These experiments show a distinct relationship between SNL-B and SNL-A. At $170^{\circ} \mathrm{C}$, SNL-B is formed in a mixture with SNL-A. With increased time at temperature, only SNL-A is formed. For example, at $120^{\circ} \mathrm{C}$ for 5-20 days, only SNL-B is formed, while at $120^{\circ} \mathrm{C}$ for 28 days, only SNL-A is formed. Also shown on the ternary plot is the stability region for $\mathrm{TiO}_{2}$ and pharmacosiderite (a known microporous $\mathrm{Cs}_{2} \mathrm{O}-\mathrm{TiO}_{2}-\mathrm{SiO}_{2}$ ion exchanger).

SNL-A is a condensed phase with a formula $\mathrm{Cs}_{2} \mathrm{TiSi}_{6} \mathrm{O}_{15}$, polymorphic to the phase synthesized at PNNL by solid-state techniques. The structure of SNL-A has been solved by structure modeling (using density functional theory calculations) and Rietveld refinement. SNL-A crystallizes in the monoclinic $(\mathrm{Cc})$ space group with unit cell parameters:

$$
\begin{aligned}
& \mathrm{a}=12.998(2) \AA \\
& \mathrm{b}=7.5014(3) \AA \\
& \mathrm{c}=15.156(3) \AA \\
& \beta=105.80(3)^{\circ} .
\end{aligned}
$$




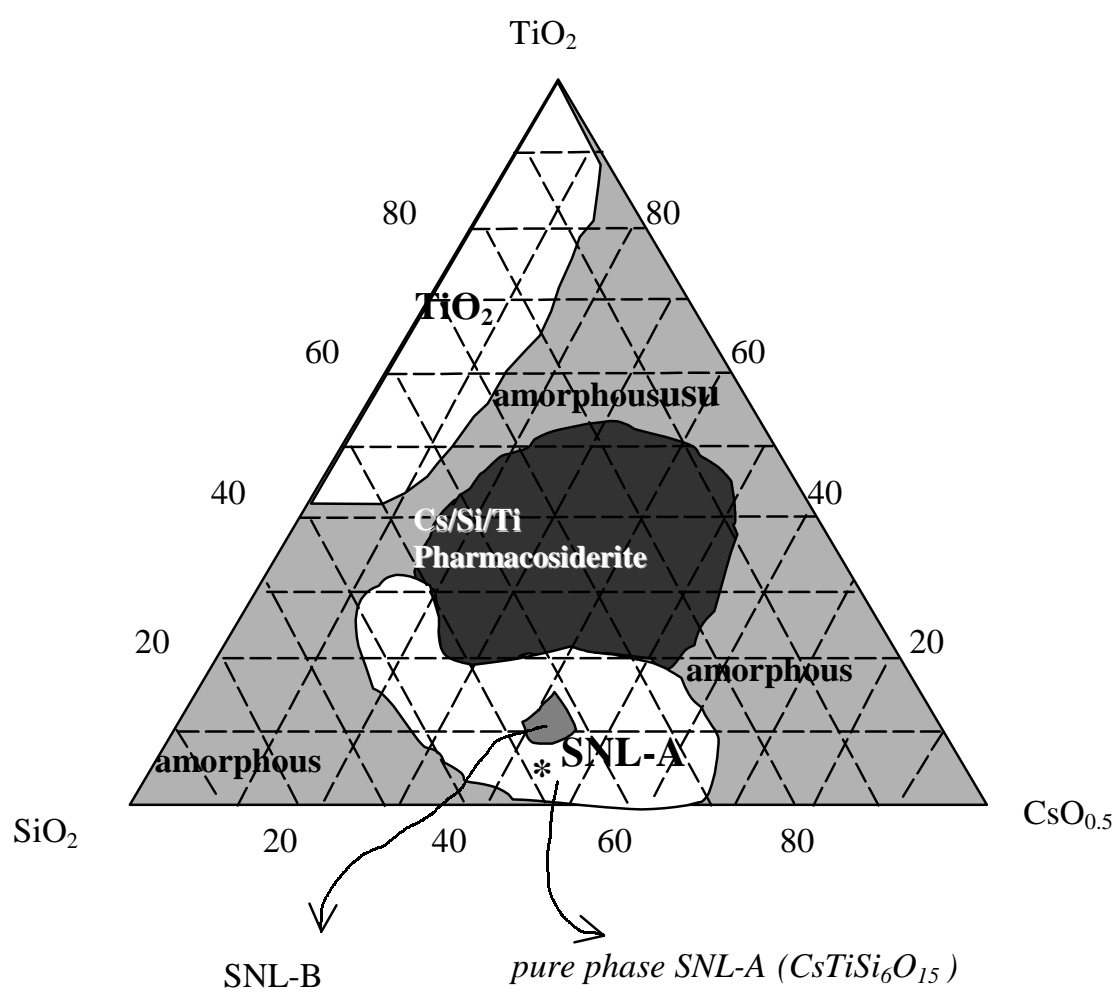

Figure 2. Stability of Hydrothermally Synthesized $\mathrm{Cs}_{2} \mathrm{O}-\mathrm{TiO}_{2}-\mathrm{SiO}_{2}$ Ternary Phases at $170^{\circ} \mathrm{C}$

The framework of SNL-A consists of silicon tetrahedra and titanium octahedra, which condense in 3-, 5-, 6-, 7- and 8-rings. The Cs ions are located cages created by the rings. PCT leach tests performed on this phase for 10 days showed $<0.2 \%$ Cs loss from the original $30 \%$ by weight Cs composition; effectively no Cs was lost due to leaching. SNL-B is a microporous ion exchanger with a chemical formula $\mathrm{Cs}_{3} \mathrm{TiSi}_{3} \mathrm{O}_{9.5} 3 \mathrm{H}_{2} \mathrm{O}$. This molecular sieve exhibits high selectivity for divalent cations. Solid-state ${ }^{133} \mathrm{Cs}$ and ${ }^{29} \mathrm{Si}$ MAS NMR and cross polarization (CP) MAS NMR of SNL-A and SNL-B reveal that both phases are structurally complex with multiple silicon and cesium coordination sites. All silicon atoms in both phases are in tetrahedral coordination. The CP-MAS NMR experiments show there is internal water in SNL-B and none in SNL-A. This is confirmed by thermogravimetry experiments.

In situ TEM-monitored electron irradiation studies of SNL-A and SNL-B were also carried out, in collaboration with Dr. Rod Ewing at the University of Michigan, to determine the stability of these new phases in radioactive environments. The irradiation-induced transformation of microporous crystalline SNL-B to amorphous material is observed by fading Bragg-diffraction spots in the electron diffraction pattern. The irradiation dose needed for amorphization of SNL-B is inversely dependent on temperature. This corresponds to heat-accelerated cesium and/or water loss, and finally a thermally induced phase change at $500^{\circ} \mathrm{C}$ (which is also observed 
by differential thermal analysis). This amorphization behavior is typical of other zeolite materials studied by Dr. Ewing. The condensed phase SNL-A, on the other hand, is very irradiation-resistant. It does not undergo any irradiation damage with very high dose rates.

\section{New Sr-Selective Microporous Ion Exchanger}

In the course of $\mathrm{Na}_{2} \mathrm{O}-\mathrm{TiO}_{2}$ hydrothermal phase searches, researchers at SNL discovered a new inorganic molecular sieve, $\mathrm{Na} / \mathrm{Nb} / \mathrm{M} / \mathrm{O}(\mathrm{M}=\mathrm{Ti}$ and $\mathrm{Zr}$ ), with extreme selectivity for divalent elements, especially Sr and RCRA ${ }^{\text {(a) }}$ metals, (Phase I is a Ti-niobate phase, Phase II is a Zr-niobate phase). They are chemically and mechanically stable, have high selectivity for divalent radwaste cations and RCRA metals, are regenerable (by back ion exchange) and thermally converted to a refractory and unreactive perovskite-based ceramic.

\section{Thermodynamic Studies Using Solution Drop Calorimetry}

Using hydrothermal methods, two series of microporous silicotitanates were synthesized at SNL: $\left(\mathrm{Na}_{1-\mathrm{x}} \mathrm{Cs}_{\mathrm{x}}\right)_{3} \mathrm{Ti}_{4} \mathrm{Si}_{3} \mathrm{O}_{13}(\mathrm{OH}) \cdot \mathrm{xH}_{2} \mathrm{O}(\mathrm{x}=4-5)$ phases with a cubic structure of $P \overline{4} 3 m$ (analogs of the mineral pharmacosiderite) and $\left(\mathrm{Na}_{\mathrm{x}} \mathrm{Cs}_{1-\mathrm{x}}\right)_{3} \mathrm{Ti}_{4} \mathrm{Si}_{2} \mathrm{O}_{13}(\mathrm{OH}) \cdot \mathrm{xH}_{2} \mathrm{O}(\mathrm{x}=4-5)$ phases with a tetragonal structure of $\mathrm{P}_{2} / \mathrm{mcm}$. The enthalpies of drop solution in molten $2 \mathrm{PbO} \cdot \mathrm{B}_{2} \mathrm{O}_{3}$ at $974 \mathrm{~K}$ were measured at UC-Davis by high-temperature reaction calorimetry, and the enthalpies of formation have been determined from constituent oxides using appropriate thermochemical cycles. The enthalpies of formation for the cubic phases become more exothermic as $\mathrm{Cs} /(\mathrm{Na}+\mathrm{Cs})$ increases, whereas those for the tetragonal phases become less exothermic. This result indicates that the cesium uptake in the cubic phases is thermodynamically favorable, whereas that in the tetragonal phases is thermodynamically unfavorable and kinetically driven. In addition, the cubic phases appear to be more stable than the corresponding tetragonal phases with the same $\mathrm{Cs} / \mathrm{Na}$ ratio. We attribute these disparities in the energetic behavior of the two series to their differences in both local bonding configuration and degree of hydration.

\section{Energetics of Ti-Substituted Pollucites}

As stated earlier, a complete solid solution series was synthesized between $\mathrm{CsAlSi}_{2} \mathrm{O}_{6}$ and $\mathrm{CsTiSi}_{2} \mathrm{O}_{6.5}$ using sol-gel method at PNNL. The structures of the solid solutions are analogous to that of cubic pollucite $\left(\mathrm{CsAlSi}_{2} \mathrm{O}_{6}\right)$, as determined by Rietveld analysis of powder synchrotron XRD data. The standard molar enthalpies of formation from the oxides for Ti-substituted pollucites were determined at UC-Davis by drop-solution calorimetry. As $\mathrm{Ti}^{4+}$ substitutes for $\mathrm{Al}^{3+}$ in pollucites, the enthalpies of formation become less exothermic, suggesting a destabilizing effect of the charge-coupled substitution, $\mathrm{Ti}^{4+}+1 / 2 \mathrm{O}^{2-} \rightarrow \mathrm{Al}^{3+}$, on the pollucite structure. Moreover, the enthalpic variation shows an exothermic mixing within the composition range

(a) RCRA=Resource Conservation and Recovery Act. 
from $\mathrm{CsTi}_{0.3} \mathrm{Al}_{0.7} \mathrm{Si}_{2} \mathrm{O}_{6.15}$ to $\mathrm{CsTiSi}_{2} \mathrm{O}_{6.5}$. This nonideal mixing behavior is consistent with the trend seen in variation of lattice parameters, and we interpret it to be a result of the short-range order associated with the framework cations $\mathrm{Al}^{3+}, \mathrm{Si}^{4+}$, and $\mathrm{Ti}^{4+}$ in the structures.

\section{Summary}

In summary, we have shown that a very durable waste form can be achieved by a simple heat treatment of the Cs-loaded ion exchanger with no additives. Direct thermal conversion reduces the total volume of waste generated from the ion exchanger by $40 \%$ and dramatically simplifies processing. Heat treatment of the ion exchanger coarsens fines, reducing inhalation risk, and removes water, eliminating radiolytic hydrogen production. The IE-911 CST ion exchanger is compositionally complex. Transmission electron microscopy, XRD, and synthesis studies have revealed that the major phases in CST are $\mathrm{Na}_{2} \mathrm{Ti}_{6} \mathrm{O}_{13}, \mathrm{Cs}_{2} \mathrm{X} 1 \mathrm{Si}_{3} \mathrm{O}_{9}$, and $\mathrm{Na}(\mathrm{Ti}, \mathrm{X} 2) \mathrm{O}_{3}$. The network structure of the cesium-containing phases precludes facile migration of the cesium ion, resulting in extremely high aqueous durability. Metastable phase-development studies have revealed two new low temperature $\mathrm{Cs} / \mathrm{Si} / \mathrm{Ti}$ phases and a novel class of niobate-based molecular sieves $(\mathrm{Na} / \mathrm{Nb} / \mathrm{M} / \mathrm{O}, \mathrm{M}=$ transition metals), which show exceptionally high selectivity for divalent cations. These niobate materials have shown orders of magnitude better selectivity for $\mathrm{Sr}^{2+}$ under acid conditions than any other material. In addition, the thermodynamic stabilities of metastable and stable compounds have been determined by solution drop calorimetry. This combined information on phase selection as a function of composition, chemical durability, and thermodynamic stability can be used to determine processing windows and to predict long- and short-term stability of thermally converted CST ion exchangers.

\section{Information Access}

Balmer ML, Y Su, IE Grey, A Santoro, RS Roth, Q Huang, N Hess, and BC Bunker. 1996. "The structure and properties of two new silicotitanate zeolites." In Scientific Basis for Nuclear Waste Management XX, W. J. Gray and I. R. Triay, eds. Vol. 465, p. 449.

Balmer ML, Q Huang, A Santoro, and R Roth. 1997a. "Neutron powder diffraction study of the crystal structure of $\mathrm{CsTiSi}_{2} \mathrm{O}_{6.5}$." J. Sol. State Chem. 130:97-102.

Balmer ML, BC Bunker, LQ Wang, CH F Peden, and Y Su. 1997b. "Solid State ${ }^{29}$ Si MAS NMR of Titanosilicates." J. Phys. Chem. 101(45):9170-9179.

Balmer ML, Y Su, H Xu, E Bitten, D McCready, and A Navrotsky. 1999. "Synthesis, structure determination, and aqueous durability of $\mathrm{Cs}_{2} \mathrm{ZrSi}_{3} \mathrm{O}_{9}$." J. Amer. Ceram. Soc. (submitted).

Grey IE, RS Roth, and ML Balmer. 1997. "The crystal structure of $\mathrm{Cs}_{2} \mathrm{TiSi}_{6} \mathrm{O}_{15}$." J. of Sol. State Chem. 131:38-42. 
McCready DE, ML Balmer, and KD Keefer. March 1997. "Experimental and calculated x-ray powder diffraction data for cesium titanium silicate, $\mathrm{Cs}_{2} \mathrm{Ti}_{2} \mathrm{Si}_{4} \mathrm{O}_{13}$ : A New Zeolite." Powder Diffraction 12(1):40-46.

Nenoff TM, JE Miller, SG Thoma, and DE Trudell. 1996. "Highly selective inorganic crystalline ion exchange material for $\mathrm{Sr}^{2+}$ in acidic solutions." Environ. Sci. Technol. 30:3630.

Nenoff TM, M Nyman, A Navrotsky, H Xu, Y Su, and ML Balmer. 1999. "Synthesis, characterization and ion exchange of novel sodium niobate phases." In Proceedings from ACS Symposium on First Accomplishments of Environmental Management Science Program, New Orleans.

Nogues JL, EY Vernaz, and N Jacquet-Francillon. 1984. In The Scientific Basis for Nuclear Waste Management, Vol. 44. CM Jantzen, JA Stone, and RC Ewing, eds. Materials Research Society.

Nyman MD, TM Nenoff, Y Su, ML Balmer, A Navrotsky, and H Xu. 1998. "CSTs: Stability and use as alternative waste forms." In Scientific Basis for Nuclear Waste Management XXII, DJ Wronkiewicz and JH Lee, eds. Vol. 556, pp. 71-76.

Nyman M and TM Nenoff. 1999. "Synthesis, characterization and ion exchange of new $\mathrm{Na} / \mathrm{Nb} / \mathrm{M} 4+/ \mathrm{OH} 2 \mathrm{O}(\mathrm{M}=\mathrm{Ti}, \mathrm{Zr})$ phases." In Proceedings from the Metal Separation Technologies Beyond 2000, Hawaii.

Nyman M, BX Gu, LM Wang, RC Ewing, and TM Nenoff. 2000. "Synthesis and characterization of a new microporous cesium silicotitanate (SNL-B) molecular sieve." J. of Microporous and Mesoporous Materials (submitted).

Su Y, ML Balmer, and BC Bunker. 1997. "Evaluation of cesium silicotitanates as an alternative waste form." In Scientific Basis for Nuclear Waste Management XX, WJ Gray and UR Triay, eds. Materials Research Society Vol. 465, pp. 457-464.

Su Y, ML Balmer, L Wang, BC Bunker, MD Nyman, T Nenoff, and A Navrotsky. 1998. "Evaluation of thermally converted silicotitanate waste forms." In Scientific Basis for Nuclear Waste Management XXII, DJ Wronkiewicz and JH Lee, eds. Vol. 556, pp. 77-84.

Su Y, ML Balmer, and BC Bunker. 2000. "Raman spectroscopic studies of silicotitanates." J. Phys. Chem. (submitted).

Xu H, A Navrotsky, ML Balmer, Y Su, E Bitten, TM Nenoff, and MD Nyman. 1999. "Thermochemistry of substituted pollucites along the CsAlSi2O6-CsTiSi2O6.5 join." EOS (American Geophysical Union 1999 Fall Meeting), Vol. 80, No. 46, F1115. 
$\mathrm{Xu} \mathrm{H}$, A Navrotsky, MD Nyman, and TM Nenoff. 2000. "Thermochemisty of microporous silicotitanate phases in the $\mathrm{Na}_{2} \mathrm{O}-\mathrm{Cs}_{2} \mathrm{O}-\mathrm{SiO}_{2}-\mathrm{TiO}_{2}-\mathrm{H}_{2} \mathrm{O}$ system." J. Materials Research 15(3) (in press).

Yanase I, H Kobayashi, Y Shibasaki, and T Mitamura. 1997. "Tetragonal-to-cubic phase transition in pollucite by low-temperature x-ray powder diffraction." J. Am. Ceram. Soc. $80: 2693$. 